\title{
Hermeneutika sebagai Metode Tafsir: Mengurai Konstruksi Pengetahuan Generasi Z Kota Malang
}

\author{
M. Miski ${ }^{* 1}$, L.F. Priyandini' ${ }^{2}$, M. R. Sudawam ${ }^{3}$, M.A.R. Wardah ${ }^{4}$, A.C. Alim ${ }^{5}$ \\ 1-5Universitas Islam Negeri Maulana Malik Ibrahim Malang, Indonesia \\ Email: miski@uin-malang.ac.id
}

\begin{abstract}
This study is intended to answer three main questions. First, how does the $\mathrm{Z}$ generation in Malang City responds to the use of hermeneutics as a method of interpreting the Qur'an by Muslim scholars? Second, how is the process of transmitting their knowledge about it? And third, how is the construction of their knowledge about the ideal interpretation of the Qur'an and can respond to socio-religious dynamics and phenomena? This study is a field study, while the primary respondents are Z generation in Malang City. The use of descriptive, hermeneutic, and intertext analysis models on data, the results of this study showed that there are differences conveyed by the $\mathrm{Z}$ generation of Malang City related to the use of hermeneutics as a method of interpretation of the Qur'an: some of them accept it, while others reject it. The transmission of their knowledge about hermeneutics also varies; most of them are correlated with social media, some are still conventional, which relies on information from teachers, and so on. This showed that generation $\mathrm{Z}$ of Malang city is not entirely averse to issues that tend to be controversial. Moreover, the authority for interpreting the Qur'an has not entirely shifted from the real world to cyberspace, no matter how dependent they are on the new media.
\end{abstract}

Keywords: Generation Z; hermeneutics; interpretation; method; transmission.

\begin{abstract}
Abstrak
Kajian ini dimaksudkan untuk menjawab tiga pertanyaan utama, yaitu bagaimana generasi Z kota Malang merespons penggunaan hermeneutika sebagai metode tafsir al-Qur'an oleh para tokoh muslim? bagaimana transmisi pengetahuan mereka? dan bagaimana pula konstruksi pengetahuan mereka tentang tafsir al-Qur'an yang ideal dan responsif terhadap dinamika dan fenomena sosial keagamaan? Kajian ini merupakan kajian lapangan dengan responden utama generasi Z kota Malang. Dengan model analisis deskriptif, hermeneutis dan interteks terhadap data yang sudah didapatkan, kajian ini menunjukkan bahwa terdapat perbedaan respons yang diberikan oleh generasi Z kota Malang terkait penggunaan hermeneutika sebagai metode tafsir; sebagian menerima, sedangkan lainnya menolak. Transmisi pengetahuan mereka tentang hermeneutika pun beragam, sebagian besar berkorelasi dengan media sosial, sebagian masih berkutat dengan transmisi pengetahuan yang masih konvensional, seperti mengandalkan informasi dari guru dan sebagainya. Hal ini menunjukkan bahwa generasi Z kota Malang tidak seluruhnya abai terhadap isu-isu yang cenderung kontroversial. Lebih dari itu, otoritas penafsiran al-Qur'an, tidak seluruhnya bergeser dalam ruang media sosial, betapa pun bergantungnya mereka dengan media baru tersebut.
\end{abstract}

Kata Kunci: Generasi Z; hermeneutika; metode; tafsir; transmisi.

\section{PENDAHULUAN}

Diskursus hermeneutika sebagai metode tafsir al-Qur'an melahirkan kontroversi (Maimun, 2015; Muslim, 2015; Reflita, 2016; Saifullah, 2018; Setiawan, 2016; Shihab, 2009; Soleh, 2011; Victoria \& Kellib, 2017; Wafa \& Supianudin, 2017). Sebagian pihak menolak dengan tegas, sedangkan pihak yang lain justru menerimanya dengan baik. Dua perbedaan respon terhadap hermeneutika ini, lahir berbagai karya yang dengan mudah bisa didapatkan, terutama di media sosial. Media baru ini dekat dengan generasi Z bahkan identik. Pada bagian ini, analisis terhadap respon generasi $\mathrm{Z}$ tentang keberadaan hermeneutika sebagai

*Corresponding Author

Received: December 29, 2020; Revised: January 03, 2021; Accepted: January 28, 2021 
Khazanah Theologia, Vol. 3 No. 1 (2021): 55-66

Hermeneutika sebagai Metode Tafsir: Menurai Konstruksi Pengetahuan Generasi Z Kota Malang M. Miski, et.al.

salah satu model tafsir al-Qur'an menjadi menarik. Limpahan literatur yang mereka dapatkan di media sosial pasti punya implikasi, baik dalam konteks memahami, menerima atau menolak hermeneutika. Implikasi tersebut merupakan resepsi yang tidak bisa dinafikan, sebagai konsekuensi dari karakter generasi $\mathrm{Z}$ yang berada pada fase pencarian jati diri. Beberapa temuan ahli menegaskan, keberadaan media sosial, ternyata tidak hanya sebagai arsip pengetahuan keislaman, namun juga telah menggeser otoritas keagamaan yang sebelumnya selalu dipertahankan. Dengan kata lain, kaitannya dengan hermeneutika, generasi Z bisa saja memiliki perspektif yang berbeda dengan generasi sebelumnya, berdasarkan literatur yang bisa diakses bebas di media sosial (Ahmadi, 2019; Jinan, 2013; Mudin, 2019).

Kajian-kajian terhadap hermeneutika sebagai metode tafsir al-Qur'an, secara garis besar memang dapat dipetakan menjadi dua kecenderungan besar: pertama, kecenderungan menolak. Di antara konstruksi argumen yang dikemukakan adalah karena hermeneutika merujuk pada salah satu dewa Yunani, Hermes, produk Barat, semula digunakan sebagai alat interpretasi Alkitab dan sebagainya. Kedua, kecenderungan menerima. Dalam hal ini, hermeneutika dinilai mampu memberikan perspektif baru, memosisikan al-Qur'an sebagai kitab suci yang responsif terhadap berbagai dinamika yang tidak didapatkan dari metode ilmu al-Qur'an dan tafsir pada umumnya, dan lain-lain. Dari kecenderungan menerima ini, muncul beberapa varian kajian lain, seperti kajian terhadap pemikiran hermeneutika para tokoh muslim, mengaplikasikan teori hermeneutika Barat dan muslim terhadap ayat-ayat al-Qur'an dan sebagainya (Abdullah \& Mudhofir, 2014; Akbar, 2005; Darmawan, 2019; Dozan \& Turmudzi, 2019; Fahmi, 2018; Farida \& Kusrini, 2013; Habibie, 2016; Hery, 2018; Malik, 2019; Martono, 2019; Miski, 2015; Muchtar, 2016; Muslim, 2015; Nawawi, 2016; Nugroho, 2016; Purkon, 2013; Reflita, 2016; Rohmah, 2016; Setiawan, 2016; Shihab, 2009; Soleh, 2011; Victoria \& Kellib, 2017; Wafa \& Supianudin, 2017). Dari semua kajian tersebut, tidak ada satu pun yang memberikan perhatian khusus terhadap bagaimana generasi $\mathrm{Z}$ merespons hal tersebut. Padahal, sebagai sebuah entitas dengan karakteristik yang khas, mereka harusnya tidak diabaikan sama sekali karena merupakan representasi dari fenomena sosial tertentu, model pemahaman metode al-Qur'an yang unik dan sebagainya.

Berpijak pada problematika di atas serta dalam rangka mengisi celah kajian sebelumnya, kajian ini akan menganalisis bagaimana generasi $\mathrm{Z}$ merespons hermeneutika sebagai salah satu metode tafsir alQur'an. Dalam melacak resepsi mereka, terdapat tiga pertanyaan utama yang akan disajikan. Pertama, bagaimana generasi Z kota Malang merespons penggunaan hermeneutika oleh para tokoh mulsim dalam menafsirkan al-Qur'an? Pertanyaan ini sebagai penegasan terhadap asumsi bahwa generasi Z punya akses lebih terhadap berbagai literatur tentang hermeneutika. Fakta ini meniscayakan mereka harus memilih sebagai sikap adaptasi terhadap literatur yang berlimpah. Terutama kaitannya dengan literatur yang menegaskan bahwa para tokoh muslim kontemporer banyak menggunakan hermeneutika sebagai metode tafsir al-Qur'an. Kedua. bagaimana transmisi pengetahuan mereka? Pertanyaan ini berkenaan dengan sumber pengetahuan keagamaan, terutama terkait hermeneutika sebagai metode tafsirkorelasinya dengan generasi Z, yakni bagaimana proses transmisi tersebut terjadi. Ketiga, bagaimana konstruksi pengetahuan mereka tentang tafsir al-Qur'an yang ideal dan responsif terhadap dinamika dan fenomena sosial keagamaan? Pertanyaan ini dalam rangka memosisikan generasi Z sebagai bagian dari kelompok yang independen dalam konteks mengayakan diskursus tentang hermeneutika secara khusus atau tafsir secara umum.

Namun, perlu ditegaskan bahwa generasi Z yang dimaksud, fokus pada yang eksis di Kota Malang. Pada laman resmi Pemerintah Kota Malang disebutkan bahwa kota Malang memiliki luas $110.06 \mathrm{Km}^{2}$. Kota dengan jumlah penduduk sampai tahun 2010 sebesar 820.243 jiwa yang terdiri dari 404.553 jiwa penduduk laki-laki, dan penduduk perempuan sebesar 415.690 jiwa. Tersebar di 5 Kecamatan: Klojen, 
Khazanah Theologia, Vol. 3 No. 1 (2021): 55-66

Hermeneutika sebagai Metode Tafsir: Menurai Konstruksi Pengetahuan Generasi Z Kota Malang M. Miski, et.al.

Blimbing, Kedungkandang, Sukun dan Lowokwaru. Secara keseluruhan, kota ini terdiri dari 57 Kelurahan, 536 unit RW dan 4.011 unit RT. Selain itu, kota ini juga mendapatkan banyak gelar bergengsi, misalnya, sebagai kota sejarah. Hal ini karena sejak awal kota Malang menyimpan misteri embrio tumbuhnya kerajaan-kerajaan besar, seperti Singosari, Kediri, Mojopahit, Demak dan Mataram. Disebut juga sebagai kota pendidikan (Pemerintah Kota Malang, n.d.). Ini pun didukung dengan fasilitas pendidikan yang memadai, baik pendidikan formal, dari tingkat Sekolah Dasar hingga Perguruan Tinggi (negeri dan swasta) maupun pendidikan non formal seperti pesantren yang jumlahnya mencapai ratusan (Lupito, 2020; Pemerintah Kota Malang, n.d.; Redaksi, 2013; Satria, 2015). Lebih dari itu, kota Malang bisa menjadi cerminan dari keragaman etnis, budaya dan agama yang saling menopang, rukun dan toleran (Pemerintah Kota Malang, n.d.). Dengan demikian, asumsi pentingnya, generasi Z di kota Malang terbiasa dengan perbedaan, perspektif yang beragam serta akses pendidikan dan ilmu pengetahuan yang mudah.

\section{METODE PENELITIAN}

Kajian ini merupakan kajian lapangan dengan model kualitatif. Keseluruhan datanya didapatkan melalui teknik wawancara. Responden yang disasar adalah para generasi Z Kota Malang. Generasi Z mengacu pada entitas yang dekat dengan internet, atau yang lahir dari 1995 hingga 2010. Terdapat tiga tema pertanyaan utama yang diajukan pada mereka, pertama, tentang sumber pengetahuan tentang hermeneutika yang mereka dapatkan. Pertanyaan pada tema ini akan sampai pada deskripsi tentang proses transmisi pengetahuan hermeneutika yang sampai pada generasi Z Kota Malang. Kedua, tema pertanyaan tentang respons generasi Z Kota Malang terhadap kenyataan banyaknya tokoh muslim yang menggunakan hermeneutika sebagai metode tafsir al-Qur'an. Pertanyaan tentang tema ini merupakan pertanyaan kritis yang bisa mengarahkan pada gambaran spesifik tentang bagaimana generasi Z Kota Malang melakukan adaptasi terhadap ragam pemikiran tafsir dan tawaran metodologis hermeneutika pada masa kontemporer. Ketiga, pertanyaan seputar penggunaan metode tafsir yang ideal dan responsif terhadap dinamika dan fenomena yang eksis pada kondisi dan situasi terkini. Melalui pertanyaan ini, bisa terlihat bagaimana cara dan model berpikir seputar ilmu tafsir terkonstruksi dalam diri generasi Z Kota Malang.

Para responden generasi Z Kota Malang dipetakan pada tiga kategori utama. Pertama, generasi Z yang memiliki pendidikan keagamaan yang kental, utamanya yang sampai saat ini masih belajar agama di pesantren. Kedua, generasi $\mathrm{Z}$ lahir, tumbuh dan tinggal di Kota Malang namun tidak sedang atau masih mengenyam pendidikan pesantren. Ketiga, generasi Z yang sebenarnya tidak lahir dan tidak tumbuh di Malang, namun tinggal di Malang dalam rangka menyelesaikan pendidikan atau lain-lain. Pemetaan generasi Z Kota Malang yang tidak seragam lebih representatif dalam rangka menjelaskan dinamika dan fenomena ini secara utuh. Semua informasi terkait pertanyaan-pertanyaan inti yang diajukan pada masing-masing responden akan dianalisis dengan tiga model analisis. Pertama, analisis deskriptif yakni terkait persoalan transmisi pengetahuan mereka tentang hermeneutika. Kedua, analisis hermeneutis. Hal ini kaitannya dengan respon generasi Z Kota Malang terhadap ragam literatur tentang hermeneutika dan bagaimana pilihan sikap mereka terhadap sebuah keputusan tertentu. Ketiga, analisis interteks, yaitu terkait dengan kenyataan bahwa apa pun yang mereka pikirkan tentang tafsir ideal dan responsif, pada dasarnya memiliki korelasi dengan hal-hal yang muncul sebelum atau saat itu. 
Khazanah Theologia, Vol. 3 No. 1 (2021): 55-66

Hermeneutika sebagai Metode Tafsir: Menurai Konstruksi Pengetahuan Generasi Z Kota Malang M. Miski, et.al.

\section{HASIL DAN PEMBAHASAN}

\section{Hermeneutika, Media Sosial dan Generasi Z: Sebuah Pemetaan}

Hermeneutika ditengarai sebagai bentuk adaptasi dari Hermes yang disebut sebagai salah satu dewa atau manusia setengah dewa di Yunani. Tugas utama Hermes adalah menyampaikan pesan dari Dewa utama pada umat manusia. Sebagai pembawa pesan, Hermes tidak bertindak secara pasif: sekedar membawa pesan. Ia juga berperan secara aktif dalam upaya agar penerima pesan bisa memahami pesan yang dibawa dengan baik. Dari kata nama Hermes, muncul istilah atau konsep hermeneutika yang merujuk pada proses atau aktivitas menjelaskan dan menafsirkan. Pada mulanya, konsep ini menjadi teori dan metode untuk menafsirkan mitos yang tengah berkembang kala itu. Selanjutnya, hermeneutika diadopsi sebagai teori dan metode dalam menafsirkan Kitab Perjanjian Lama dan Kitab Perjanjian Baru. Seiring berjalannya waktu, hermeneutika tidak hanya digunakan untuk menafsirkan teks agama, melainkan sebagai metode tafsir untuk bidang sosial dan apa pun yang diposisikan sebagai teks. Ia terus berkembang, melahirkan tokoh besar dan aliran-aliran yang terus eksis dengan karakteristiknya yang beragam (Gracia, 2014; Kippenberg et al., 2010; Schmidt, 2006).

Perlu dijelaskan, meskipun hermeneutika lahir dan berkembang dari tradisi Barat, namun pada kenyataannya ia diadopsi dan diaplikasikan dalam tradisi Timur, termasuk dalam dunia Islam. Dalam dunia Islam, hermeneutika banyak digunakan sebagai metode dan teori untuk menafsirkan al-Qur'an dan hadis. Namun demikian, keberadaan hermeneutika dalam tradisi Islam melahirkan kontroversi yang tidak kunjung selesai, sebagian menerima dan sebagian menolak. Bagi yang menerima, hermeneutika dianggap mampu memberikan tawaran metodologis baru untuk bisa mengikis kebekuan metode-metode yang pernah ada sebelumnya. Tawaran hermeneutika sebagai basis metodologi tafsir al-Qur'an dinilai bisa menempatkan al-Qur'an sebagai kitab suci yang selalu relevan dalam segala situasi dan kondisi. Sedangkan bagi yang menolak, hermeneutika disebut tidak korelatif dengan al-Qur'an. Selain sejak awal al-Qur'an sudah memiliki basis metodologis sendiri: ilmu al-Qur'an dan tafsir, hermeneutika muncul dari Barat dan sejak awal digunakan sebagai teori dan metode teks suci lain sehingga dianggap tidak relevan jika digunakan untuk al-Qur'an (Darmawan, 2019; Dozan \& Turmudzi, 2019; Maimun, 2015; Malik, 2019; Muslim, 2015; Nawawi, 2016; Reflita, 2016; Saifullah, 2018; Setiawan, 2016; Shihab, 2009; Soleh, 2011; Victoria \& Kellib, 2017; Wafa \& Supianudin, 2017).

Terlepas dari perbedaan respon para ahli terhadap hermeneutika al-Qur'an, implikasi positifnya terdapat banyak karya penting terkait ilmu tersebut yang dapat diakses dengan mudah, terutama di media sosial. Media sosial menjadi tempat pengarsipan data tentang hermeneutika, hermeneutika al-Qur'an dan sebagainya. Dalam melacak literatur-literatur tersebut, pengguna media sosial cukup dengan menggunakan kata kunci atau konsep khusus, seperti "Hermeneutika," "Hermeneutika al-Qur'an," "Hermeneutika sebagai metode tafsir" dan sebagainya. Kata kunci atau konsep-konsep itu layaknya katalog dalam sistem perpustakaan konvensional. Melalui kata kunci atau konsep ini, pengguna media sosial akan diarahkan pada ragam literatur yang memang memuat hal tersebut. Lebih dari itu, hal tersebut juga dapat diakses kapan pun, di mana pun dan oleh siapa pun. Dalam konteks ini, media sosial menjadi medium baru yang memudahkan setiap pengguna saling terhubung, antarsesama pengguna, mudah mendapatkan pengetahuan hanya dengan sekali tekan dan lain-lain.

Media sosial, secara sederhana dipahami sebagai sebuah ruang dalam dunia virtual, online atau dunia maya. Ruang ini diposisikan sebagai bentuk antitesa dari ruang nyata yang biasa dijalani sebelum keberadaan internet. Media sosial berasal dari dua kata: media dan sosial. Kata media bisa merujuk pada pengertian alat, wadah, sarana atau teknologi. Sedangkan kata sosial bisa dipahami sebagai masyarakat. 
Khazanah Theologia, Vol. 3 No. 1 (2021): 55-66

Hermeneutika sebagai Metode Tafsir: Menurai Konstruksi Pengetahuan Generasi Z Kota Malang

M. Miski, et.al.

Saat dua kata ini menjelma sebagai kata majemuk, secara terminologi, biasanya merujuk pada pengertian: sebuah medium berbasis internet. Medium ini menjadi wadah representasi diri bagi para pengguna internet. Medium ini sekaligus difungsikan sebagai sarana berinteraksi, bekerjasama, berkomunikasi dan membentuk ikatan sosial secara virtual antarsesama pengguna. Medium tersebut mencakup segala jenis bentuk media sosial seperti, mesin pencarian Google, Facebook, Instagram, YouTube, WhatsApp, Twitter dan lain-lain. Terlepas dari kenyataan bahwa masing-masing media sosial punya karakteristik yang bisa menjadi pembeda dengan jenis media sosial lainnya, namun, secara umum, segala jenis media sosial identik dengan beberapa aspek utama, antara lain: arsip dan penyebaran. Keberadaan media sosial mengakomodir berbagai jenis data, materi dan informasi yang bisa diakses dan disebarkan kembali secara bebas tanpa bisa dikendalikan (Mudin, 2019; Nasrullah, 2017).

Media sosial sangat dekat dengan kehidupan masyarakat dunia kontemporer. Media sosial merupakan representasi dari globalisasi dan kemajuan teknologi-informasi yang kemudian bertransformasi ke dalam dunia internet. Pada 2020, disebutkan, pengguna media sosial aktif di dunia mencapai 3,8 milyar dari total populasi 7,75 milyar. Data ini berbeda dengan data yang muncul 2019 yang menegaskan bahwa pengguna media sosial aktif masyarakat dunia mencapai 3,5 milyar dari jumlah populasi 7,68 milyar. Hal ini berarti ada peningkatan yang signifikan dari 2019 hingga 2020. Bagaimana dengan Indonesia? Penelitian yang sama menyebutkan, pengguna media sosial aktif di Indonesia mencapai 160 juta dari total populasi 272,1 juta dengan rata-rata menghabiskan waktu sampai 3 jam, 26 menit setiap harinya. Secara spesifik, laporan itu menyebutkan pengguna Youtube di Indonesia sebanyak 88\%; pengguna Whatsapp sebanyak 84\%; pengguna Facebook sebanyak 82\% dan pengguna Instagram sebanyak 79\% dari jumlah populasi di Indonesia (We Are Social \& Hootsuite, 2019, 2020).

Entitas pengguna media sosial terkini, baik dalam konteks dunia secara umum maupun indonesia secara khusus, generasi $Z$ disebut sebagai generasi yang paling identik dengan media sosial. Secara khusus, generasi ini disebut sebagai generasi internet. Teori generasi menyebutkan, generasi Z merupakan generasi keempat dari lima generasi yang diperkenalkan oleh para ahli. Pertama, "Generasi Baby Boomer," yaitu generasi yang lahir 1946 hingga 1964; kedua, generasi X yakni generasi yang lahir antara 1965 hingga 1980; ketiga, generasi Y yaitu generasi yang lahir antara 1981 hingga 1994; keempat, generasi Z yakni generasi yang lahir dari 1995 sampai 2010; generasi ini disebut juga dengan istilah iGeneration; kelima, generasi Alpha, yaitu yang lahir kisaran tahun 2011 hingga 2025. Masing-masing generasi ini lahir sesuai dengan kondisi dan situasi teknologi-informasi yang berkembang di zamannya. Generasi Z lahir dan dibesarkan pada era digital dan merasakan sendiri kecanggihan teknologi-informasi. Mereka pun memiliki kemampuan tinggi dalam mengakses dan mengakomodasi berbagai informasi di media sosial. Alasan ini pula yang membentuk generasi Z menjadi lebih terbuka dibandingkan generasi sebelumnya (Mukhlis, 2015).

\section{Hermeneutika dalam Proses Transmisi Pengetahuan Generasi Z Kota Malang}

Kemampuan individu untuk membaca, menulis, berbicara, dan memahami merupakan hal penting yang digunakan dalam mendefinisikan suatu pengetahuan. Melalui pengertian ini dapat dipahami bahwa literasi bukan hanya sekadar membaca dan menulis, melainkan lebih kepada suatu keterampilan yang dibutuhkan untuk menunjukan bagaimana seseorang dapat mentransformasikan teks yang telah dibaca kepada suatu hasil pemahaman tertentu. Dewasa ini akses yang digunakan untuk mencari literatur dalam mendukung para akademisi mengembangkan ilmu pengetahuan tertentu tidaklah sulit. Era digital yang kian pesat berkembang menjadikan segala informasi bisa dicapai hanya dari ujung jari. 
Khazanah Theologia, Vol. 3 No. 1 (2021): 55-66

Hermeneutika sebagai Metode Tafsir: Menurai Konstruksi Pengetahuan Generasi Z Kota Malang

M. Miski, et.al.

Dalam memahami metodologi tafsir, generasi Z kota Malang disuguhkan dengan berbagai macam metode yang pernah digunakan para mufasir untuk mengkaji al-Qur'an dari berbagai aspek; seperti metode tahlili (analitis), ijmali (global), muqarrin (perbandingan), dan maudhu'i (tematik). Dalam hal ini, hermeneutika sebagai metode penafsiran yang dinilai lahir dari Barat turut andil berkontribusi dalam khazanah keilmuan tafsir. Mengenai hal tersebut, generasi Z Kota Malang secara tidak langsung sudah disuguhi wawasan dasar untuk menggambarkan seperti apa hermeneutika yang dahulunya digunakan untuk menafsirkan Bibel, kemudian diadaptasi sebagai metode untuk menginterpretasikan al-Qur'an. Oleh karena itu literatur bacaan dan lingkungan akademis sebagian besar menentukan seberapa besar pemahaman mereka terhadap hermeneutika ini.

Hasil wawancara mengenai transimisi pengetahuan generasi Z kota Malang tentang hermeneutika dapat dipetakan pada beberapa kategori. Pertama, sebagian responden menyatakan bahwa sumber asal pengetahuan mereka adalah literatur, baik literatur digital/online maupun literatur cetak, seperti buku akademik, jurnal ilmiah dan sebagainya. Data ini menunjukkan bahwa akses yang digunakan responden untuk mencari makna hermeneutika lebih besar menggunakan media literatur digital. Hal ini tentu wajar karena sebagian besar mahasiswa menganggap handphone, laptop, dan alat bantu serupa lebih mudah digunakan dan praktis. Mengenai hal ini AR (19) mengatakan:

Saya baru mendengar istilah Hermeneutika pertama kali ketika menginjak semester 5 ini, dan saya mencari informasi apa itu hermeneutika melalui beberapa web, diantaranya: Wikipedia, serta halaman web republika.co.id dan saya juga mencari wawasan dalam beberapa artikel atau file pdf yang ada di google (AR, Komunikasi Personal, 9-10 September 2020).

Kedua, sebagian responden menjelaskan bahwa pengetahuan tentang hermeneutika selain dari beragam literatur, juga ada yang didapat dari relasi individu yang telah ada. Dalam hal ini RS mengungkapkan: "Awalnya dari kakak kelas yang kuliah di Jogja, namun hanya sebatas tahu istilah, kemudian di bangku kuliah ini baru mengetahui secara lebih luas baik dari membaca jurnal maupun seminar atau keterangan dari dosen (RS (21), Komunikasi Personal, 9-10 September 2020)." Ketiga, sebagian besar responden menyatakan bahwa pengetahuan tentang hermeneutika didapatkan secara langsung di bangku perkuliahan. Hal ini mengindikasikan bahwa peran dosen dalam perkuliahan dianggap punya kontribusi besar untuk mendukung pehamahan mahasiswa tentang hermeneutika. Dalam hal ini AM mengatakan: "Pada Awalnya dari dosen melalui pembelajaran di kelas. Kemudian dari salah satu guru yang juga menjadi dosen yang sering mengajak saya diskusi." (AM, Komunikasi Personal, 910 September 2020). Keempat, sebagian kecil responden menyatakan bahwa tidak ada referensi dasar yang digunakan untuk mengetahui hermeneutika secara khusus.

\section{Hermeneutika dan Upaya Adaptasi Ragam Tawaran Metodologi Hermeneutis}

Meskipun sejak awal hermeneutika disadari muncul dan berkembang di Barat, namun, tidak semua responden menolak keberadaan hermeneutika sebagai salah satu metode tafsir al-Qur'an. Pandangan yang demikian menjadi pandangan yang paling dominan di kalangan generasi Z kota Malang. Berdasarkan hasil wawancara, sebagian besar merespons positif terhadap para tokoh muslim yang menggunakan hermeneutika dalam menafsirkan al-Qur'an. Terdapat beberapa alasan yang disebutkan oleh mereka, antara lain: pertama, menurut mereka, para tokoh tersebut tentu telah memiliki landasan dan pengetahuan yang mumpuni untuk bisa menerapkan hermeneutika dalam menafsirkan al-Qur'an. Mereka juga berpendapat bahwa para ulama tersebut tentu memperhatikan penerapan kaidah-kaidah penafsiran terdahulu. Secara lebih jelas, ZA (22) menegaskan: 
Khazanah Theologia, Vol. 3 No. 1 (2021): 55-66

Hermeneutika sebagai Metode Tafsir: Menurai Konstruksi Pengetahuan Generasi Z Kota Malang

M. Miski, et.al.

Menurut saya, beberapa tokoh muslim itu pastinya sudah mempertimbangkan sebab dan akibat dalam pilihannya untuk menggunakan hermeneutika sebagai metode tafsirnya. Mereka juga pastinya sudah mengetahui kaidah-kaidahnya. Pasti mereka tidak asal-asalan dalam menerapkan metode hermeneutika ini dalam metode tafsirannya. Sebagaimana diketahui bahwa tafsir itu relatif kebenarannya, banyak penafsiran berbeda di antara ulama klasik tentang al-Qur'an. Maka begitu pula pada penggunaan hermeneutika ini. Mereka mencoba berijtihad untuk membuka wawasan berfikir manusia agar tidak stagnan pada satu metode dan satu keilmuan saja, serta menyelaraskannya dengan zaman, membuktikan bahwa al-Qur'an ini memang bisa diterapkan dalam berbagai zaman. Sehingga kembali lagi bahwa segala sesuatu yang tersembunyi itu hakikatnya hanya Allah yang mengetahui kebenarannya, tugas kita sebagai manusia hanya berusaha menggali terus keilmuan kita dan menemukan kebaikan positif yang memang berguna dan baik bagi kita (ZA, Komunikasi Personal, 9-10 September 2020).

Alasan kedua, hermeneutika sesuai dengan perkembangan zaman yang memang dinamis. Dalam hal ini IA (21) menegaskan: "Hal demikian boleh saja, karena hermeneutika dengan berbagai kontroversinya tidak lantas dapat dinafikan keberadaannya dan ditolak produk tafsirnya, hal demikian untuk penyesuaian nilai agama dengan kehidupan kontemporer." (IA, Komunikasi Personal, 9-10 September 2020). Tentu, selain alasan tersebut, penerimaan terhadap hermeneutika juga didasarkan pada kesadaran bahwa tidak cukup alasan untuk menolak hermeneutika karena pada kenyataannya, ia merupakan sebuah keilmuan yang sudah matang layaknya keilmuan tafsir pada umumnya.

Sedangkan respon negatif yang diberikan oleh generasi Z Kota Malang, di antaranya beralasan, sebab hermeneutika merupakan metode yang produk tafsirnya banyak yang bertentangan dengan hasil tafsir ulama pada ulama. Dalam hal ini SM (21) menegaskan, "Saya berpendapat dari sisi hasil hermeneutika tersebut. Setahu saya kebanyakan hasil hermeneutikanya bertentangan dengan hasil tafsir ulama pada umumnya, terlepas dari itu jika dipikir secara lumrahnya kehidupan muslim pun hasil dari hermeneutika dalam metode tafsir itu kurang bisa diterima (SM, Komunikasi Personal, 9-10 September 2020);" serta alasan tidak ditemukannya tafsir al-Qur'an -khususnya di Indonesia- yang menggunakan metode hermeneutika dalam penafsirannya.

\section{Konstruksi Pengetahuan Hermeneutika di Kalangan Generasi Z Kota Malang}

Paparan pada subbab sebelumnya menjelaskan bahwa sebagian besar generasi Z kota Malang yang menjadi responden memberikan respon positif terhadap penggunaan hermeneutika dalam memahami al-Qur'an yang dilakukan oleh tokoh-tokoh muslim. Hal ini berarti bahwa memang sebagian kecil memberikan respon negatif. Secara lebih jelas, subbab ini diarahkan untuk mendapatkan gambaran yang lebih komprehensif tentang konstruksi pengetahuan mereka terkait tema ini.

Secara lebih jelas, generasi $\mathrm{Z}$ kota Malang juga berbeda dalam konstruksi pengetahuan hermeneutika sebagai salah satu metode tafsir al-Qur'an. Sebagian mendukung; sebagian menolak. Mereka yang mendukung memiliki alasan yang beragam meskipun -sekali lagi-berakhir dengan kesimpulan yang sama: menerima penggunaan hermeneutika sebagai metode tafsir al-Qur'an. Secara keseluruhan, alasan-alasan yang dikemukakan dapat dipetakan pada poin-poin berikut. Pertama, hermeneutika dinilai sebagai sebuah disiplin keilmuan yang bisa dipelajari untuk menambah khazanah keilmuan khususnya dalam bidang tafsir. Ia banyak dipakai sebagai epistemologi tafsir kontemporer pada masa sekarang yang dipelopori mufasir kontemporer. Selain itu, menurut mereka, tidak ada yang salah belajar tentang hermeneutika sebagai metode penafsiran, meskipun latar belakang kemunculannya berasal dari luar Islam. Bagi mereka, dengan mempelajarinya justru akan bisa diketahui perbedaan antara metode tafsir yang sudah ada dengan hermeneutika, sehingga bisa menjadi sebuah perbandingan antara 
Khazanah Theologia, Vol. 3 No. 1 (2021): 55-66

Hermeneutika sebagai Metode Tafsir: Menurai Konstruksi Pengetahuan Generasi Z Kota Malang

M. Miski, et.al.

dua keilmuan yang substansinya sama yaitu menafsirkan ayat Al-Qur'an (IA, VM, FZ, LH, AW, FA, HF, AI, Komunikasi Personal, 9-10 September 2020). Dalam hal ini, IA (21) menegaskan, "Hermeneutika merupakan bagian dari epistemologi tafsir kontemporer, jadi untuk mengetahui dan memperkaya pengetahuan kita sebagai mahasiwa IAT khususnya untuk ikut mempelajari salah satu metode tafsir kontemporer tersebut (IA, Komunikasi Personal, 9-10 September 2020)."

Kedua, konsep hermeneutika pada hakikatnya sama dengan tafsir. Secara sederhana hermeneutika diartikan sebagai seni dan ilmu untuk menafsirkan teks-teks suci-dalam hal ini al-Qur'an-dan merupakan bagian dari penafsiran menggunakan akal atau ijtihad (RS (21), SM (20), AF (20), LP (20), AZ (21), AS (21), YZ (20), FM (21), WK (21), HA (22), DQ (21), Komunikasi Personal, 9-10 September 2020). SR (20), menegaskan, "Kerangka hermeneutika tidak jauh berbeda dari tafsir ulama klasik. Bahkan saya belum menemukan perbedaan selain nama dan asal-usulnya (SR, Komunikasi Personal, 9-10 September 2020)."

Ketiga, penafsiran al-Qur'an menggunakan metode hermeneutika dinilai sebagai penafsiran yang ilmiah dan sesuai dengan tuntutan zaman. Penafsiran secara hermeneutis dianggap sebagai penafsiran yang ilmiah melihat metode ini mengikuti kerangka berfikir filsafat yang mencoba menyajikan sebuah informasi yang sarat akan rasionalitasnya. Penafsiran ini sesuai dengan perkembangan zaman dibuktikan dengan keterbukaan metode ini dalam mengungkap ayat berdasarkan gagasan-gagasan baru yang bermunculan seperti HAM, gender dan sebagainya. Hermeneutika dinilai mampu melahirkan hasil penafsiran yang luas disebabkan dialektika antara ayat yang turun di masa dahulu dan diinterpretasi ulang sesuai dengan kondisi pada masa sekarang. Selain itu, metode ini bisa digunakan sebagai alternatif untuk mencari pesan yang belum ada pada karya tafsir klasik (SA (19), DF (20), MA (21), ZA (22), KH (20), AY (22), SS (21), RZ (20), NA (20), Komunikasi Personal, 9-10 September 2020). Lebih jauh ZA (22), menegaskan:

Hermeneutika bisa dijadikan sebagai salah satu metode tafsir, tetapi tidak sepenuhnya. Karena menurut saya memang tidak ada salahnya menjelaskan al-Qur'an dengan berbagai metode pendekatan. Jikalau itu malah menjadikan al-Qur'an semakin kuat dan bisa membuktikan bahwa al-Qur'an ini bisa difahami dan selaras dengan perkembangan zaman yang memang terus berkembang dinamis. Karena dengan adanya hermeneutika ini juga bisa memperkaya khazanah ilmu penafsiran sebagai tambahan, pelengkap, atau bubuhan saja agar hasil pemahaman terhadap al-Qur'an itu semakin lengkap. Selain itu jika dengan hermeneutika ini, kita bisa membuktikan pada barat bahwa al-Qur'an ini memang benar-benar kalam Allah yang bisa merasuk dalam berbagai zaman. Apalagi kalau sampai bisa membawa orang non islam masuk islam karena adanya penelitian pada al-Qur'an dengan metode ini. Maka itu akan memberi keuntungan juga bagi kita, selaku umat Islam (ZA, Komunikasi Personal, 9-10 September 2020)."

Keempat, hermeneutika tetap bisa digunakan selama ia tidak dijadikan sebagai metode utama dalam penafsiran, melainkan sebagai metode penunjang dan tetap memepertimbangkan kaidah-kaidah tafsir yang ada. Penggunaan hermeneutika diharapkan mampu menghasilkan produk tafsir yang benar dan sesuai dengan syariat Islam. Menurut mereka produk tafsir hermeneutis yang bermasalah harus dikesampingkan mengingat produk tafsir yang sudah ada sekalipun tidak semuanya diterima dan banyak juga yang menuai permasalahan dan komentar-komentar dari ulama lain (NS (20), LF (20), CM (20), NA (22), NW (20), LM (20), SI (20), Komunikasi Personal, 9-10 September 2020). Dalam hal ini, NW (20), mengatakan:

Mengutip perkataan M. Quraish Shihab yang berpandangan bahwa tidak semua penafsiran yang dilakukan oleh pakar hermeneutika merupakan sesuatu/persepsi yang keliru, pastinya masih terdapat sesuatu yang baik dan dapat diambil pelajaran khususnya dalam konteks penafsiran kitab 
Khazanah Theologia, Vol. 3 No. 1 (2021): 55-66

Hermeneutika sebagai Metode Tafsir: Menurai Konstruksi Pengetahuan Generasi Z Kota Malang

M. Miski, et.al.

suci umat Islam (misalnya dengan tetap meninjau kondisi sosial, adat dan budaya yang ada pada saat ayat turun). Pada dasarnya hermeneutika ialah alat yang digunakan untuk memahami teks dan menggali kebenaran. Sama halnya dengan tujuan penafsiran, dari sini menurut saya jika hermeneutika hanya dianggap sebagai metode interpretasi terhadap teks maka selaras dengan tujuan penafsiran. Namun, juga perlu untuk tetap berhati-hati dan menjadikan kaidah-kaidah tafsir sebagai patokan. Di sini saya bukan berarti menerima sepenuhnya. Anggap saja hermeneutika sebagai suatu ilmu pengethaun yang menurut saya tidak ada salahnya jika mempelajari suatu ilmu, hal yang baik dapat diambil (tentunya sesuai dengan ajaran terdahulu), yang kurang atau bahkan menyeleweng dapat dikesampingkan (NW , Komunikasi Personal, 9-10 September 2020).

Sedangkan, kelompok yang tidak setuju hermeneutika dijadikan metode tafsir memberikan beberapa alasan, antara lain: pertama, latar belakang hemeneutika yang lahir dari Barat dan digunakan untuk menafsirkan Bibel. Bagi mereka, Bible berbeda dengan al-Qur'an. Ia dianggap tidak otentik, sedangkan al-Qur'an yang merupakan firman Allah punya nilai sakralitas dan otentik. Dengan menggunakan hermeneutika sebagai metode tafsir al-Qur'an, dikhawatirkan akan menghilangkan nilai otentisitas dan kesakralannya (AR (19), CN (21), Komunikasi Personal, 9-10 September 2020). Dalam hal ini, CN (21) menegaskan,

Hermeneutika biasa diterapkan dalam teks-teks yang diragukan keotentikannya, sedangkan alQur'an merupakan kalamullah yang pasti terjaga autentisitasnya dan penerapan hermeneutika dalam menafsirkan al-Qur'an akan berbahaya jika tidak dilakukan dengan ekstra hati-hati dan juga mendatangkan resiko negatif dalam studi al-Qur'an (CN, Komunikasi Personal, 9-10 September 2020).

Alasan lain yang disampaikan kelompok ini dalam menolak keberadaan hermeneutika sebagai metode tafsir adalah karena belum ada satu karya tafsir bernuansa hermeneutis yang terbukukan sebagaimana kitab-kitab tafsir dari ulama terdahulu seperti Jami' al-Bayan karya Ibnu Jarir al-Thabari, Tafsir al-Qur-an al-'Azim karya Ibnu Katsir serta kitab-kitab tafsir lain yang sudah terbukukan dan mewarnai khazanah penafsiran Al-Qur'an dalam dunia Islam. Dalam hal ini, mereka lebih memilih tafsir klasik yang sudah pasti metodenya yakni tafsir klasik daripada menggunakan metode baru yang belum dimengerti dalam penggunaanya (HH (22), AM (20) Komunikasi Personal, 9-10 September 2020). Namun, ada juga yang menolak hermeneutika dengan alasan ketidaktahuan akan konsep hermeneutika yakni sebagai bentuk kehati-hatian (DR (20), TR (18) Komunikasi Personal, 9-10 September 2020). Demikian sebagaimana yang disampaikan oleh DR. Dia mengatakan: "Karena saya belum mempelajarinya, jadi saya tidak setuju, terlalu berbahaya bagi saya yang awam, entah besok kalau sudah belajar dan memahaminya" (DR, Komunikasi Personal, 9-10 September 2020.

\section{Tafsir Ideal dan Responsif ala Generasi Z kota Malang: Sebuah Catatan Rumusan}

Selain paparan yang sudah dijelaskan, terdapat beberapa penjelasan lebih dalam yang berhasil dihimpun selama proses wawancara, yaitu, bagaimana generasi Z kota Malang mengandaikan keberadaan tafsir yang dinilai ideal dan responsif terhadap terhadap berbagai persoalan kontemporer. Secara umum, penjelasan mereka dapat dikelompokkan pada beberapa kecenderungan pemikiran. Pertama, sebagian besar responden yang ditemui mendukung adanya metode baru yang muncul di era kontemporer salah satunya metode hermeneutika. Alasannya, metode ini dianggap relevan dan dapat memayungi perkembangan zaman yakni semakin pesatnya kemajuan teknologi serta kebutuhan manusia yang terus meningkat. Penggunaan metode hermeneutika ini dianggap mampu menjawab permasalahan terkini yang baru muncul setelah masa klasik. 
Khazanah Theologia, Vol. 3 No. 1 (2021): 55-66

Hermeneutika sebagai Metode Tafsir: Menurai Konstruksi Pengetahuan Generasi Z Kota Malang

M. Miski, et.al.

Kedua, sebagian menjelaskan dan meyakini bahwa metode klasik adalah metode yang lebih efektif dan menjadi ilmu dasar penafsiran, sehingga adanya metode baru tidaklah boleh untuk menyaingi atau menyalahi keberadannya. Sebab metode klasik dianggap telah sukses berkiprah dari zaman ke zaman dan sangat memperhatikan riwayat. Ketiga, sebagian mereka menyebutkan bahwa metode yang paling ideal dan responsif tidak hanya metode baru maupun klasik, melainkan metode yang mengombinasikan dua metode itu sekaligus. Namun, dalam hal ini metode baru berada pada posisi melengkapi sehingga mampu melahirkan produk-produk tafsir klasik dan mampu tetap hidup di masa sekarang. Keduanya dapat saling bersinergi untuk memproduksi tafsir yang solutif dan responsif terhadap masa dewasa ini. Kombinasi ini dianggap mampu menyokong satu sama lain, mengingat sebuah tafsir yang tidak bisa terlepas dari kelemahan/kekurangan. Keempat, bagi sebagian responden, idealitas sebuah metode tafsir sebenarnya tidak terikat oleh keberadaan metode itu sendiri, tetapi begantung pada situasi dan kondisi yang melingkupi. Metode klasik bisa saja menjadi pilihan terbaik di masanya, demikian pula metode kontemporer menjadi metode paling relevan dengan situasi dan kondisi kontemporer.

Memperhatikan uraian di atas, beserta uraian-uraian pada subbab-subbab sebelumnya, dapat terlihat bagaimana konstruksi pengetahuan hermeneutika generasi Z kota Malang, meliputi respon terhadap penggunaan hermeneutika oleh tokoh-tokoh muslim kontemporer dalam aktivitas penafsiran al-Qur'an dan meliputi proses transmisi pengetahuan mereka terkait tema ini. Dapat diketahui pula generasi Z kota Malang tidak jauh berbeda dengan generasi milenial dan generasi sebelumnya dalam merespons hermeneutika; sebagian menerima, sedangkan sebagian yang lain menolak. Titik pembeda yang paling kentara dengan generasi sebelumnya terletak pada keberlimpahan literatur yang memungkinkan mereka lebih cepat memutuskan pilihan metode sekaligus memungkinkan mereka lebih terbuka sejak dini terhadap berbagai perbedaan pendapat di kalangan para ahli, utamanya korelasinya dengan tema ini. Hal lain yang dapat diungkap melalui kajian ini adalah bahwa kelekatan generasi Z kota Malang dengan media sosial, tidak serta mereka bahwa transmisi pengetahuan mereka tentang heremeneutika otomatis bersumber dari media baru tersebut. Meskipun media baru menjadi tempat mencari jawaban dari ragam pertanyaan keagamaan-termasuk soal hermeneutika-namun ia bukan satusatunya sumber pengetahuan mereka. Kenyataannya, sebagian mereka masih berpijak pada sumber pengetahuan konvensional.

\section{SIMPULAN}

Berpijak pada tiga pertanyaan utama di atas, kajian ini menunjukkan bahwa sejak awal respons mereka terhadap hermeneutika sebagai salah satu metode tafsir al-Qur'an kontemporer beragam. Secara umum, keragaman tersebut dapat dipetakan pada dua kecenderungan utama: menerima sebagai keniscayaan dinamika keilmuan; menolak karena tidak relevan dari semua aspeknya. Respons yang beragam ini terlihat dari saat mereka mendapati banyak tokoh muslim kontemporer yang menggunakan metode dan pendekatan tersebut terhadap al-Qur'an. Lebih dari itu, transmisi pengetahuan generasi Z kota Malang sebagian besar berkorelasi dengan keberadaan media sosial. Media baru ini menjadi tempat pencarian mereka dalam persoalan hermeneutika. Namun, sebagian tetap menggunakan cara konvensional, seperti melalui dosen, teman sejawat dan sebagainya. Perbedaan tersebut juga terlihat dari bagaimana mereka mengandaikan kemungkinan sebuah metode atau pendekatan khusus yang ideal dan respons terhadap ragam dinamika terkini. Sebagian menegaskan bahwa hermeneutika dapat menjadi alternatif paling relevan; sebagian bersikukuh pada aspek romantisme keilmuan tafsir bahwa metode dan 
Khazanah Theologia, Vol. 3 No. 1 (2021): 55-66

Hermeneutika sebagai Metode Tafsir: Menurai Konstruksi Pengetahuan Generasi Z Kota Malang M. Miski, et.al.

pendekatan dalam tafsir klasik tetap sebagai metode yang paling relevan dengan situasi dan kondisi terkini.

\section{REFERENSI}

Abdullah, \& Mudhofir. (2014). Kesejarahan al-Qur'an dan Hermeneutika. Journal of Qur'an and Hadith Studies, 3(1), 57-77. https://doi.org/10.1548/QUHAS.V3I1.1163

Ahmadi, R. (2019). Kontestasi atas Otoritas Teks Suci Islam di Era Disrupsi: Bagaimana Kelas Menengah Muslim Indonesia Memperlakukan Hadis melalui Media Baru. Jurnal Studi Agama dan Masyarakat, 15(1), 22-35. https://doi.org/10.23971/jsam.v15i1.1138

Akbar, A. (2005). Tawaran Hermeneutika untuk Menafsirkan Alquran. Wacana, Journal of the Humanities of Indonesia, 7(1), 50. https://doi.org/10.17510/wjhi.v7i1.290

Darmawan, D. (2019). Hermeneutika sebagai Metode Baru dalam Menafsirkan al-Quran. Journal of Chemical Information and Modeling, 53(9), 1689-1699. https://doi.org/10.1017/CB09781107415324.004

Dozan, W., \& Turmudzi, M. (2019). Konsep Hermeneutika Sebagai Metodologi Interpretasi Teks AlQur'an. MAGHZA: Jurnal Ilmu Al-Qur'an dan Tafsir, 4(2), 205-219. https://doi.org/10.24090/maghza.v4i2.3470

Fahmi, L. (2018). Hermeneutika Emillio Betti dan Aplikasinya dalam Menafsirkan Sistem Kewarisan 2:1 pada Surat an-Nisa Ayat 11. Ulul Albab: Jurnal Studi dan Penelitian Hukum Islam, 2(1), 143-173. https://doi.org/10.30659/jua.v2i1.3120

Farida, E. N., \& Kusrini. (2013). Studi Islam Pendekatan Hermeneutik. Jurnal Penelitian, 7(2), 381404.

Gracia, J. J. E. (2014). A Theory of Textuality: The Logic and Epistemology. New York: State University of New York Press, Albany.

Habibie, M. L. H. (2016). Hermeneutika dalam Kajian Islam. At-Tibyan, 1(1), 211-242.

Hery, M. (2018). Hermeneutika Insider-Ousider: Studi Atas Pengaruh Heremeneutika Barat Terhadap Heremeneutika Islam. TAMADDUN: Jurnal Kebudayaan dan Sastra Islam, 17(2), 120-138. https://doi.org/10.19109/tamaddun.v18i2.2391

Jinan, M. (2013). Intervensi New Media dan Impersonalisasi Otoritas Keagamaan di Indonesia. Jurnal Komunikasi Islam, 03(02), 321-348.

Kippenberg, H. G., Wasserstrom, S. M., Alles, G. D., Dubuisson, D., Faivre, A., \& Rennie, B. (2010). Hermeneutics, Politics, and the History of Religions (C. Wedemeye \& W. Doniger, Ed.). New York: Oxford University Press, Inc.

Lupito, A. (2020). Bupati Malang Klaim Ratusan Ponpes Sudah Terapkan Pesantren Tangguh.

Maimun, A. (2015). Resistensi terhadap Hermeneutika dalam Kajian Al-Qur'an di Indonesia. Suhuf, $8(2), 233-260$.

Malik, R. K. (2019). Hermeneutika al-Qur'an dan Debat Tafsir al-Qur'an: Implementasinya dengan Masa Kini. At-Turās: Jurnal Studi Keislaman, 6(1), 56-76.

Martono, M. (2019). Kajian Kritis Hermeneutika Friederich Scheiermacher VS Paul Ricoeur. Jurnal Edukasi Khatulistiwa, 2(1), 42-48. https://doi.org/10.26418/ekha.v1i1.31713

Miski. (2015). Hermeneutika al-Quran Kontemporer. Hermeneutik, 9(2), 423-446.

Muchtar, M. I. (2016). Analisis Konsep Hermeneutika Dalam Tafsir Alquran. HUNAFA: Jurnal Studia Islamika, 13(1), 67. https://doi.org/10.24239/jsi.v13i1.414.67-89

Mudin, M. (2019). ISLAM VIRTUAL, Diskursus Hadis, Otoritas, dan Dinamika Keislaman di Media Sosial (1 ed.; N. Afifah, Ed.). Yogyakarta: BILDUNG.

Mukhlis, H. (2015). Pahami Remaja Generasi-Z. AF Magazine, (November), 4-7. 
Khazanah Theologia, Vol. 3 No. 1 (2021): 55-66

Hermeneutika sebagai Metode Tafsir: Menurai Konstruksi Pengetahuan Generasi Z Kota Malang

M. Miski, et.al.

Muslim, A. S. (2015). Problematika Hermeneutika Sebagai Metode Tafsir Al-Qur'an. Empirisma, 24(1), 47-55. https://doi.org/10.30762/empirisma.v24i1.5

Nasrullah, R. (2017). Media Sosial : Perspektif Komunikasi, Budaya, dan Sosioteknologi. Bandung: Remaja Rosdakarya.

Nawawi, A. M. (2016). Hermeneutika Tafsir Maudhu'i. Suhuf, 9(1), 1-14.

Nugroho, M. A. (2016). Hermeneutika al-Qur'an Hasan Hanafi; Merefleksikan Teks pada Realitas Sosial dalam Konteks Kekinian. Millati: Journal of Islamic Studies and Humanities, 1(2), 187208. https://doi.org/10.18326/MLT.V1I2.187-208

Pemerintah Kota Malang. (n.d.). Sekilas Malang.

Purkon, A. (2013). Pendekatan Hermeneutika dalam Kajian Hukum Islam. AHKAM : Jurnal Ilmu Syariah, 13(2), 183-192. https://doi.org/10.15408/ajis.v13i2.930

Redaksi. (2013). Kelebihan dan Keuntungan Kuliah di kota Malang.

Reflita. (2016). Kontroversi Hermeneutika sebagai Manhaj Tafsir. Jurnal Ushuluddin, 24(2), 135149.

Rohmah, L. (2016). Hermeneutika Al-Qur'an: Studi Atas Metode Penafsiran Nasr Hamid Abu Zaid. HIKMAH Journal of Islamic Studies, XII(2), 223-244.

Saifullah, M. (2018). Menimbang Kritik Adnin Armas atas Hermeneutika Alquran. SHAHIH: Journal of Islamicate ..., 3. https://doi.org/10.22515/shahih.v3i1.1284

Satria, L. (2015). Kota Malang Deklarasikan Kerukunan Antar Agama.

Schmidt, L. K. (2006). Understanding Hermeneutics. Durham: Acumen.

Setiawan, A. (2016). Hermeneutika al-Qur'an "Mazhab Yogya." Jurnal Studi Ilmu-ilmu Al-Qur'an dan Hadis, 17(1), 69-96. https://doi.org/10.14421/qh.2016.1701-04

Shihab, Q. (2009). Tafsir, Ta 'wil, dan Hermeneutika. Suhuf, 2(1), 1-10.

Soleh, A. K. (2011). Membandingkan Hermeneutika dengan Ilmu Tafsir. TSAQAFAH, 7(1), 31-50. https://doi.org/10.21111/tsaqafah.v7i1.106

Victoria, A., \& Kellib, A. (2017). Kontroversi Hermeneutika Sebagai Manhaj Tafsir. Jurnal Hukum Khaira Ummah, 12(1), 1-10.

Wafa, W., \& Supianudin, A. (2017). Masuknya Hermeneutika dalam Lingkup Ilmu Tafsir. Jurnal alTsaqafa, 14(1), 206-212. https://doi.org/10.1038/132817a0

We Are Social \& Hootsuite. (2019). Digital 2019. We Are Social \& Hootsuite, 76.

We Are Social \& Hootsuite. (2020). Digital 2020. In Global Digital Insights. https://doi.org/https://datareportal.com/reports/digital-2020-global-digital-overview 